\title{
STUDY KASUS TOTAL PRODUKSI PUCUK TEBU (Saccharum Officinarum L) SEBAGAI PAKAN TERNAK DI KABUPATEN MALANG
}

\author{
Case Study of Total Production of Sugarcane Top (Saccharum officinarum L) as \\ Feedstuff at Malang Regency
}

\author{
Hanif Fathur Rohman ${ }^{1)}$, Hanief Eko Sulistyo ${ }^{2)}$ \\ 1) Mahasiswa Fakultas Peternakan, Universitas Brawijaya, Malang, Jawa Timur, Indonesia, 65145 \\ ${ }^{2)}$ Dosen Bagian Nutrisi dan Makanan Ternak, Fakultas Peternakan, Universitas Brawijaya, Malang, Jawa Timur, \\ Indonesia, 65145 \\ Email: haniffathur10@gmail.com
}

\begin{abstract}
ABSTRAK
Riset dilakukan untuk mengetahui produktivitas limbah pucuk tebu di lahan irigasi dan lahan non irigasi diukur dengan beberapa parameter. Survei lapangan dan observasi laboratorium dilakukan untuk pengambilan data. Data yang diperoleh dianalisis menggunakan uji T tidak berpasangan. Hasil penelitian menunjukkan bahwa lahan sawah irigasi dan lahan sawah tadah hujan memiliki perbedaan yang sangat nyata $(\mathrm{P}<0,01)$ pada panjang pucuk tebu, jumlah daun, berat pucuk tebu, pada limbah pucuk tebu. Berbeda nyata $(\mathrm{P}<0,05)$ pada produksi bahan kering, bahan organik, dan protein kasar. Perbedaan unsur hara serta ketersediaan air pada lahan sawah irigasi dan lahan sawah tadah hujan menyebabkan perbedaan produktivitas serta nilai nutrisi pucuk tebu. Perbedaan dilahan sawah irigasi dan lahan sawah tadah hujan disebabkan tanaman tebu di lahan sawah irigasi lebih tercukupi kebutuhan unsur hara serta pertumbuhan yang normal daripada tanaman tebu yang berada dilahan sawah tadah hujan.
\end{abstract}

Kata Kunci : Bahan Kering, bahan organik, produksi pucuk tebu, protein kasar

How to Cite:

Rohman, H. F., \& Sulistyo, H. E (2021). Study Kasus Total Produksi Pucuk Tebu (Saccharum officinarum l) Sebagai Pakan Ternak di Kabupaten Malang. Jurnal Nutrisi Ternak Tropis 4 (2) 103-108
*Corresponding author:

Hanif Fathur Rohman

Email: haniffathur10@gmail.com

Fakultas Peternakan, Universitas Brawijaya, Malang, Jawa Timur, Indonesia, 65145 


\section{ABSTRACT}

Sugarcane is a waste of sugarcane plants that can be considered as a forage of cattle feed. However, the quality of the juice will be given to you. Planting sugarcane irrigated paddy fields and raindrops land has provisions and productivity and also quality. The aims of this study was to determine the productivity of sugarcane top waste on irrigated land and non irrigated land measured. The method used in this study is a field survei method and laboratory experiment. The data obtained were analyzed using the unpaired T test. The results showed that irrgated land and non irrigated land had a highly significant different $(P<0.01)$ on the length of sugarcane top, number of leaves, sugarcane top production, dry matter, organic matter and crude protein on sugarcane top waste. Differences in the characteristics of irrigated land and non irrigated land cause differences in the productivity of sugarcane top. The productivity of sugarcane top in irrigated land showed that the growth of sugarcane top is better when compared to non irrigated land. This is because in irrigated land nutrient absorption and water requirements in sugarcane are met.

Keywords: Crude protein, dry matter, organic matter, sugarcane top production

\section{PENDAHULUAN}

Potensi pucuk tebu dari areal penanaman tebu tahun 2017 sebesar 430.363 ha dengan produksi tebu sebanyak 2.121.671 ton, dengan produksi limbah pucuk tebu mencapai 4.985 ton (Direktorat Jenderal Perkebunan, 2018). Tanaman tebu ditebang pada waktu musim kemarau untuk mendapatkan rendemen dan mutu gula yang baik. Musim kemarau ketersediaan hijauan pakan ternak berupa rumput segar sukar diperoleh sehingga pada umumnya peternak di sekitar perkebunan tebu akan memanfaatkan pucuk tebunya sebagai pakan ternak. Pemanenan tebu dilakukan secara bergilir untuk menyesuaikan kapasitas pabrik gula yang terbatas, sehingga limbah pucuk tebu dapat kontinyu diperoleh sepanjang musim kemarau.

Sawah irigasi mendapatkan pengairan melalui saluran-saluran yang dibuat untuk mengalirkan air dari tempat lain (Adiningsih dkk., 2007; Jonizar dan Martini, 2016). Tanaman tebu yang tumbuh di lahan kering maupun lahan sawah akan menjalani fase-fase pertumbuhan selama masa pertumbuhannya hingga sebelum menghasilkan gula (nira), yaitu: 1). fase perkecambahan selama 0 - 1 bulan setelah tanam, 2). fase penunasan (pertumbuhan cepat) selama 1 - 3 bulan setelah tanam, 3). fase pemanjangan batang selama 3 - 9 bulan setelah tanam, 4). fase kemasakan atau kematangan (generatif maksimum) selama 10 - 12 bulan setelah tanam (Pramuhadi, 2011).Inkonsistensi baik hasil penelitian terkait dengan produksi tebu, masih menunjukan hasil yang inkonsisten. Ada beberapa cara untuk menentukan berdasarkan studi literature maupun studi kasus. Studi kasus adalah bagian dari review yang membantu untuk peneliti dalam menelaah suatu topik yang menjadi masalah (Adli dan Sjofjan, 2021).

\section{METODOLOGI PENELITIAN}

\section{Materi Penelitian}

Materi yang digunakan dalam penelitian ini adalah populasi tanaman tebu (Saccharum officinarum l.) varietas BL berumur 12 bulan yang ditanam di lahan sawah irigasi seluas $600 \mathrm{~m}^{2}$ dan di lahan sawah tadah hujan seluas $300 \mathrm{~m}^{2}$ dan jenis tanah regosol dan latosol. Bahan-bahan yang digunakan untuk analisis proksimat bahan kering, bahan organik dan protein kasar yaitu $\mathrm{NaOH}, \mathrm{H}_{2} \mathrm{SO} 4$, Aquadest dan Indikator (Suparjo, 2010). Peralatan yang digunakan untuk pemanenan tebu meliputi trash bag ukuran $60 \times 80 \mathrm{~cm}$, timbangan digital, tali raffia, spidol, kertas label, meteran dan sabit. Peralatan yang digunakan untuk analisis 
proksimat yaitu oven $105^{\circ} \mathrm{C}$, timbangan analitik, cawan porselen, eksikator, tang penjepit, hot plate, tanur, kawat pendorong, labu kjeldahl, destilator, erlenmeyer, buret dan gelas ukur (Suparjo, 2010).

\section{Metode Penelitian}

Metode yang digunakan adalah studi kasus pada budidaya tanaman tebu di lahan sawah irigasi dan lahan sawah tadah hujan dataran tinggi Malang. Data hasil penelitian

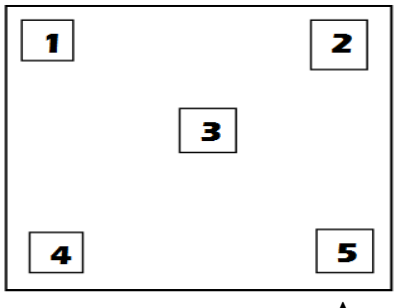

Gambar 1. Denah pengambilan sampel di lahan

A. Sawah Irigasi B. Sawah Tadah Hujan

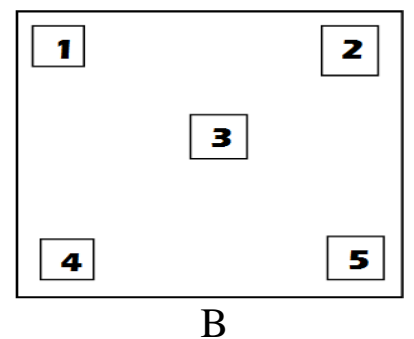

dianalisis $U j i-t$ tidak berpasangan. Sampel pucuk tebu ditentukan secara purposive sampling dengan cara mengambil dari 5 lokasi dalam lahan yaitu 1. lahan bagian depan kiri, 2. bagian depan kanan, bagian tengah lahan, 4 . bagian belakang lahan dan 5. bagian belakang kanan lahan. Pengambilan pucuk tebu dari tiap lokasi lahan berasal dari 10 tanaman tebu terdiri dari:

\section{HASIL DAN PEMBAHASAN}

Hasil pengamatan produktivitas hijauan pucuk tebu di lahan sawah irigasi (SI) dan lahan sawah tadah hujan (STD) dataran tinggi Kabupaten Malang meliputi beberapa parameter yaitu jumlah daun, panjang pucuk tebu, berat pucuk tebu, produksi BK, produksi BO dan produksi PK dapat dilihat pada Tabel 1 sebagai berikut:

Tabel 1. Hasil pengamatan produktivitas hijauan pucuk tebu di lahan sawah irigasi (SI) dan lahan sawah tadah hujan (STD) Kabupaten Malang.

\begin{tabular}{llll}
\hline Perlakuan & Jumlah daun(helai) & Panjang pucuk tebu $(\mathrm{cm})$ & Berat pucuk tebu $(\mathrm{Kg})$ \\
\hline SI & $7,60 \pm 1,23^{\mathrm{a}}$ & $183.43 \pm 18,03^{\mathrm{a}}$ & $0,21 \pm 0,02^{\mathrm{a}}$ \\
STD & $5,80 \pm 1,72^{\mathrm{b}}$ & $168,35 \pm 22,02^{\mathrm{b}}$ & $0,19 \pm 0,04^{\mathrm{b}}$ \\
\hline
\end{tabular}

${ }^{\mathrm{ab}}$ Superskrip tak sama menunjukkan berbeda sangat nyata $(\mathrm{P}<0,01)$.

\section{Jumlah Daun}

Hasil analisis uji-t tidak berpasangan menunjukkan bahwa pada parameter jumlah daun pucuk tebu terdapat perbedaan yang sangat nyata $(\mathrm{P}<0,01)$ antara kedua perlakuan yaitu lahan sawah irigasi dan lahan sawah tadah hujan. Menurut James (2004) daun tebu melekat pada batang disetiap buku-buku, secara bergantian dalam dua baris di sisi berlawanan. Daun tebu merupakan daun tidak lengkap, karena hanya terdiri dari pelepah, helai, pangkal daun, tanpa tangkai daun. Pelepah memeluk batang, makin ke atas makin sempit. Bagian pelepah terdapat bulu-bulu dan telinga daun. Daun tebu memiliki pelepah yang kuat, biasanya berwarna putih dan cekung pada permukaan atas daun, dan hijau pucat dan cembung di permukaan bawah daun.

Pada Tabel 1 menunjukkan bahwa parameter jumlah daun tebu pada perlakuan lahan sawah irigasi sebesar 7,60 helai/tanaman lebih banyak dibandingkan dengan perlakuan lahan sawah tadah hujan sebesar 5,80 helai/tanaman. Kendala yang mempengaruhi hasil tanam di lahan sawah tadah hujan adalah suplai air yang tidak memadai, dikarenakan air sungai yang mengalir ke areal persawahan tidak mampu menjangkau areal tersebut, sebab areal persawahan tersebut termasuk areal yang tinggi (Jonizar dan Martini, 2016; Felania, 
2017). Kekeringan pada sel tanaman dibedakan dalam tiga tingkatan, yaitu: A. Tingkat ringan: jika potensial air sel tanaman sedikit menurun sampai $-0,5 \mathrm{Mpa}, \mathrm{B}$. Tingkat sedang: jika potensial air dalam sel tanaman menurun sampai antara $-0,5$ dan 1,2 MPa atau antara - 0,5 dan -1,5 Mpa, C. Tingkat berat: jika potensial air sel tanaman kurang dari -1,5 MPa (Ai, N. S dan A. A. Lenak, 2014). Marsha dkk. (2014) mengemukakan air digunakan oleh tanaman untuk melangsungkan proses pembelahan dan pembesaran sel yang terlihat dari pertambahan tinggi tanaman, perbanyakan jumlah daun, dan pertumbuhan akar. Oleh karena itu, kekurangan air yang terjadi di lahan sawah tadah hujan menyebabkan jumlah daun di lahan sawah tadah hujan sedikit.

\section{Panjang Pucuk Tebu}

Panjang pucuk yang diamati pada saat proses panen berdasarkan hasil analisis uji-t tidak berpasangan menunjukkan terdapat perbedaan sangat nyata antara perlakuan lahan sawah irigasi dan lahan sawah tadah hujan $(\mathrm{P}<0,01)$. Tanaman tebu memiliki mata tunas untuk melindungi tebu dari berbagai penyakit tanaman (Erlina dkk., 2017). Panjang daun pucuk tebu merupakan batang muda beserta daunnya yang masih dapat dikonsumsi oleh ternak ruminansia.

Tabel 1 menunjukkan bahwa jumlah daun pada lahan sawah tadah hujan lebih sedikit dibandingkan dilahan sawah irigasi. Beberapa indikator yang mempengaruhi dalam produksi hijauan adalah curah hujan dan daya tampung kapasitas air. (Dainty dkk., 2016). Sehingga lahan mengalami kekeringan pada musim kemarau, yang berakibat gagal panen dan gagal tanam merupakan hal yang sangat lumrah dialami oleh petani tadah hujan (Perwitasari dkk. 2016).

\section{Berat Pucuk Tebu}

Berat pucuk tebu yang diamati pada saat proses panen diperoleh hasil analisis ujit tidak berpasangan menunjukkan terdapat perbedaan sangat nyata $(\mathrm{P}<0,01)$ antara lahan sawah irigasi dan lahan sawah tadah hujan.

Hal ini sangat mempengaruhi fase pertumbuhan tanaman tebu khususnya pada perkecambahan, pembentukan anakan, dan pemanjangan batang yang pada akhirnya akan menurunkan hasil tebu (Ramadhan dkk., 2014). Faktor lain yang mempengaruhi berat pucuk tebu yaitu $\mathrm{pH}$ tanah, $\mathrm{Ph}$ pada lahan irigasi yaitu, 6.0 dan dilahan kering $5.5, \mathrm{pH}$ tanah mempunyai pengaruh terhadap produksi dan warna pada daun, hal ini dijelaskan oleh pernyataan dari Raharjeng, (2015) $\mathrm{pH}$ merupakan indikator untuk menentukan kualitas tanaman yang akan dihasilkan.

\section{Produksi BK, BO, PK}

Hasil analisis uji-t tidak berpasangan pada parameter produksi BK, BO dan PK pucuk tebu terdapat perbedaan yang nyata $(\mathrm{P}<0,05)$ antara kedua perlakuan lahan sawah irigasi dan lahan sawah tadah hujan.

Hal ini menunjukkan bahwa tanaman Tebu varietas BL yang ditanam di lahan irigasi dataran tinggi Malang, tercukupi kebutuhan nutrisinya yang meliputi cahaya matahari, $\mathrm{CO} 2, \mathrm{O} 2$, air dan unsur hara sehingga produksi pucuk tebu meningkat melebihi penanaman di lahan kering.

Tabel 2.

\begin{tabular}{lccc}
\hline Perlakuan & Jumlah daun (helai) & Panjang pucuk tebu $(\mathrm{cm})$ & Berat pucuk tebu $(\mathrm{Kg})$ \\
\hline SI & $7,60 \pm 1,23^{\mathrm{a}}$ & $183.43 \pm 18,03^{\mathrm{a}}$ & $0,21 \pm 0,02^{\mathrm{a}}$ \\
STD & $5,80 \pm 1,72^{\mathrm{b}}$ & $168,35 \pm 22,02^{\mathrm{b}}$ & $0,19 \pm 0,04^{\mathrm{b}}$ \\
\hline
\end{tabular}

${ }^{\mathrm{ab}}$ Superskrip tak sama menunjukkan berbeda sangat nyata $(\mathrm{P}<0,01)$

Faktor irigasi memegang peran penting karena cuaca cerah pada musim kemarau menyediakan cahaya matahari cukup sepanjang hari, diiringi penyediaan air yang cukup untuk meningkatkan tekanan turgor tanaman sehingga stomata daun terbuka sempurna untuk fiksasi $\mathrm{CO} 2$ dalam proses fotosintesis menghasilkan 
karbohidrat. Dengan demikian, produk karbohidrat yang tinggi menjamin produksi BK, BO dan PK yg tinggi, setelah karbohirat mengalami proses metabolisme lebih lanjut. Haryanti, (2012) parameter bahan kering tergantung pada beberapa faktor yaitu sinar matahari, proses fotosintensis, dan gangguan hama. Dalam penelitian Koten, (2013) dikemukakan beberapa faktor yang mempengaruhi yaitu umur panen, produksi hijauan, proses fotosintesis, dan akumulasi air dalam tanaman (Kamlasi dkk., 2014).

\section{KESIMPULAN}

Produktivitas hijauan pucuk tebu pada budidaya tanaman tebu di lahan irigasi lebih tinggi daripada di lahan kering khususnya pada parameter panjang pucuk tebu, berat pucuk tebu dan jumlah pucuk tebu, yaitu masing-masing sebesar 7,60 helai/tnm, 0,21 $\mathrm{kg} / \mathrm{tnm}$ dan $183,43 \mathrm{~cm} / \mathrm{tnm}$ di lahan sawah irigasi dan 5,89 helai/tnm, $0,19 \mathrm{~kg} / \mathrm{tnm}$ dan $168,35 \mathrm{~cm} / \mathrm{tnm}$ di lahan sawah tadah hujan.Produksi BK, BO dan PK hijauan pucuk tebu pada budidaya tanaman tebu di lahan sawah irigasi lebih tinggi daripada di lahan sawah tadah hujan, yaitu masingmasing sebesar 75,58 gr/tnm, 67,21 g/tnm dan 1,68 g/tnm di lahan sawah irigasi dan $53,69 \mathrm{~g} / \mathrm{tnm}, 48,60 \mathrm{~g} / \mathrm{tnm}$ dan $1,17 \mathrm{~g} / \mathrm{tnm}$ di lahan sawah tadah hujan.

\section{DAFTAR PUSTAKA}

Adiningsih, J. S., Sofyan, A., \& Nursyamsi, D. (2007). Lahan Irigasi dan Pengelolaannya Dalam Sumber Daya Lahan Indonesia dan Pengelolaannya. Pusat Penelitian Tanah dan Agroklimat Badan Penelitian dan Pengembangan Pertanian Departemen Pertanian.

Adli, D. N., \& Sjofjan, O. (2020). Metaanalisis: pengaruh substitusi jagung dengan bahan pakal lokal terhadap kualitas karkas daging broiler. Jurnal Ilmu Peternakan Terapan, 3(2), 4448. https://doi.org/10.25047/jipt.v3i2. 1940
Agustono, B., Lamid, M., Ma'ruf, A., \& Purnama, M. T. E. (2018). Identifikasi limbah pertanian dan perkebunan sebagai bahan pakan inkonvensional di Banyuwangi. Jurnal Medik Veteriner, 1(1), 12-22. https://doi.org/ 10.20473/jmv.vol1.iss 1.2017.12-22

Badan Pusat Statistik Kabupaten Malang. (2018). Kabupaten Malang Dalam Angka. BPS Kabupaten Malang.

Dainty, I., Abdullah, S., \& Priyati, A. (2016). Analisis peluang curah hujan untuk penetapan pola dan waktu tanam serta pemilihan jenis komoditi yang sesuai di desa masbagik kecamatan masbagik Kabupaten Lombok Timur. Jurnal Ilmiah Rekayasa Pertanian Dan Biosistem, 4(1), 207-216.

Direktorat Jenderal Perkebunan. (2018). Statistik Perkebunan Indonesia Komoditas Tebu 2017-2019. Sekretariat Jenderal Perkebunan.

Dwiratna, S., Suryadi, E., \& Kamaratih, K. (2016). Optimasi pola tanam pada lahan sawah tadah hujan di Kecamatan Cimanggung Kabupaten Sumedang. Jurnal Teknotan, 10(1), 37-45. https://doi.org/10.24198/jt.vol 10n1.6

Erlina, Y., Wicaksono, K. P., \& Barunawati, N. (2017). Studi pertumbuhan dua varietas tebu (saccharum officinarum 1.) dengan jenis bahan tanam berbeda. Jurnal Pro, 5(1), 33-38.

Felania, C. (2017). Pengaruh ketersedian air terhadap pertumbuhan kacang hijau (Phaceolus radiatus). Prosiding Seminar Nasional Pendidikan Biologi Dan Biologi, B131-B138.

Haryanti, S. (2012). Respon pertumbuhan jumlah dan luas daun nilam (pogostemon cablin benth) pada tingkat naungan yang berbeda. Respon Pertumbuhan Jumlah, 2(2), 20-26. https://doi.org/10.14710/baf.v16i2.2590

James, G. (2004). Sugarcane. Blackwell Publishing Company.

Jonizar, J., \& Martini, S. (2016). Analisa ketersediaan air sawah tadah hujan di 
desa mulia sari Kecamatan Muara Telang Kabupaten Banyuasin. Jurnal Penelitian dan Kajian Teknik Sipil, 4(4), 1-5. https://doi.org/10.32502/ jbearing.695201644

Kamlasi, Y., Mullik, M. L., \& Dato, T. O. D. (2014). Pola produksi dan nutrisi rumput Kume (Shorgum plumosum var. Timorense) pada lingkungan alamiahnya. Jurnal Ilmu-Ilmu Peternakan (Indonesian Journal of Animal Science), 24(2), 31-40.

Khuluq, A. D. (2016). Potensi pemanfaatan limbah tebu sebagai pakan fermentasi probiotik. Buletin Tanaman Tembakau, Serat \& Minyak Industri, 4(1), 37-45. https://doi.org/10.21082/ bultas.v4n1.2012.37-45

Koten, B. (2013). Tumpangsari Legum Arbila (Phaseolus Lunatus L) Berinokulum Rizobium Dengan Sorgum (Sorghum Bicolor (L) Moench) Dalam Upaya Meningkatkan Produktivitas Hijauan Pakan Ruminansia. Universitas Gajah Madah.

Marsha, N. D., Aini, N., \& Sumarni, T. (2014). Pengaruh frekuensi dan volume pemberian air pada pertumbuhan tanaman Crotalaria mucronata Desv. Jurnal Produksi
Tanaman, 2(8), 673-678.

Nio, S. A., \& Lenak, A. A. (2014). Penggulungan daun pada tanaman monokotil saat kekurangan air. Jurnal Bios Logos, 4(2), 48-55. https:// doi.org/10.35799/jbl.4.2.2014.5539

Pramuhadi, G. (2016). Faktor iklim pada budidaya tebu lahan kering. Jurnal Pangan, 19(4), 331-344.

Raharjeng, A. R. P. (2015). Pengaruh faktor abiotik terhadap hubungan kekerabatan tanaman Sansevieria trifasciata L. Jurnal Biota UIN Raden Fatah, 1(1), 33-41.

Ramadhan, I. C., Taryono, \& Wulandari., R. (2015). Keragaan pertumbuhan dan rendemen lima klon tebu (Saccharum officinarum L.) di ultisol, vertisol, dan inceptisol. Vegetalika, 3(4), 77-87. https://doi.org/10.22146/veg.5763

Suparjo. (2010). Analisis Bahan Pakan Secara Kimiawi: Analisis Proksimat dan Analisis Serat. Fakultas Peternakan Universitas Jambi.

Widawati, S. (2010). The effect of salinity to activity and effectivity phosphate solubizing bacteria on growth and production of paddy. Proc. Intem. Conf. On Biol. Sci. Faculty Of Biology. 